\title{
Hybrid introgression: the outcomes of gene flow in birch
}

\author{
Kesara Anamthawat-Jónsson \\ Institute of Life and Environmental Sciences, University of Iceland, Sturlugata 7, IS-101 Reykjavík, Iceland \\ e-mail: kesara@hi.is
}

Received 28 Jun 2019

Accepted 30 Jun 2019

\begin{abstract}
Understanding life history of natural forest and woodland is important as we need to prepare for, to cope with and to tackle problems associated with the ongoing global environmental changes. The present paper focuses on one of the world's terrestrial biomes, the arctic tundra, which is a type of biome where the tree growth is hindered by low temperatures and short growing seasons. A severe threat to tundra is global warming, which causes permafrost to melt affecting species survival, and which releases soil-bound carbon in the form of greenhouse gases. Tundra vegetation is composed of dwarf shrubs, sedges and grasses, mosses and lichens - a woodland type of vegetation dominated primarily by birch shrubs. The aim of this paper is to summarize and highlight my thirty three years of genetic studies of birch woodlands in Iceland, from the discovery of introgressive hybridization in birch and estimating the extent of introgression, to uncovering past hybridization events since the end of the last glaciation about 9000 years ago. The studies use different approaches, from cytogenetic and botanical, to molecular and palynological. The overall results show clearly that hybridization between B. nana and B. pubescens is widespread in Iceland; the resulting gene flow via introgressive hybridization is bi-directional; and that the process is continuous through time and space. Iceland could be considered a birch hybrid zone, harbouring genetic variation which may be advantageous in subarctic regions. However, waves of hybridization associated with climate warming could drive one of the species into extinction.
\end{abstract}

KEYWORDS: Betula, cytogenetics, Holocene, introgressive hybridization, molecular genetics, mountain birch, palynology

\section{Hybrid introgression in plants - its positive and negative outcomes}

Introgressive hybridization (hybrid introgression, introgression) is a process by which hybridization leads to gene flow between species through backcrossing of the hybrid with its parental species ${ }^{1,2}$. The process allows for the transfer of neutral or adaptive traits from one species to another and can increase genetic polymorphism in one or both species. First there must be hybridization, whereby plants, from the same or different species, hybridize and form viable hybrid offspring. Hybridization in flowering plants is relatively common. It is estimated that a frequency of natural hybrids worldwide is not less than $10 \%$ among a quarter of a million plant species described in floras ${ }^{3}$, but on average around $25 \%$ of plant species are known to hybridize with at least one other species ${ }^{4}$. Some plant families and genera appear to have more reported hybrids than others and the characteristics associated with these hybridizing genera include perennial habit, outcrossing breeding systems and asexual reproductive modes that allow stabilization of hybrid reproduction ${ }^{5-8}$. For example, in the ginger family Zingiberaceae, where plants propagate mainly by rhizomes, the majority of Thai species in the turmeric genus Curcuma are triploid hybrids 9. Although hybrid speciation seems most likely in families or genera with high rates of contemporary hybridization, rare hybridization events can be evolutionary important. As with introgression it requires only a few partially fertile hybrids for the gene flow to occur through backcrossing. Numerous cases of hybridization and introgression have been documented and these include plants in natural habitats, between crops and wild species, and in breeding programmes ${ }^{4,10-14}$. Hybridization may contribute to speciation through the formation of new hybrid taxa, whereas introgression of a few loci may promote adaptive divergence and so facilitate speciation.

Introgressive hybridization can have positive or negative evolutionary consequences. The positive side is that it allows for the transfer of neutral or adaptive traits from one species to another and 
can increase genetic polymorphism in one or both parental species. The introgression from wild to crop species, such as rice, wheat, soybean, tomato and sunflower, via assisted hybridization has been shown to be the most immediate and effective means of improving fitness and adaptation of crops to current environmental changes ${ }^{12,14,15}$. Genomic and functional approaches reveal a case of adaptive introgression in forest tree species, from Populus balsamifera (balsam poplar) to P. trichocarpa (black cottonwood) ${ }^{16}$. Gene flow, via introgressive hybridization, appears to bring about an increase of additive variance, compared with that introduced by mutation in the same time frame, as it can transfer blocks of genes associated with adaptive traits ${ }^{17,18}$. Gene flow by hybridization has the potential to introduce large sets of new alleles simultaneously at multiple unlinked loci, which allows adaptation even for polygenic traits, ${ }^{4,17}$ and can thus promote rapid species evolution. Adaptive introgression can improve a complex trait such as fitness in the recipient pool in just a few generations, whereas with neutral introgression functional variants could be lost by drift across generations ${ }^{14}$. Introgressive hybridization may have a negative outcome, such as an evolution of aggressive weeds ${ }^{11}$, or result in the extinction of a species ${ }^{10,19}$. The harmful effects of hybridization, with or without introgression, have led to the extinction of many populations and species, especially problematic for rare species that come into contact with other species that are more abundant. The present paper discusses the outcomes of hybrid introgression in Icelandic birch.

\section{Hybrid introgression in birch - hybridization across species boundary}

Birch (Betula) is a genus of about $35-50$ species distributed throughout the temperate, boreal and arctic regions of the Northern Hemisphere. There is no consensus on species limits in Betula, with different authors differing widely in what species they accept, from under 30 species to over 60 . Morphological variation in birch (Betula) is known to be extensive, due in part to frequent hybridization in this genus ${ }^{20-24}$. This has made taxonomy of Betula problematic. According to Flora Europeae, only four Betula species are recognized for Europe ${ }^{22}$ : two tree-birch species, i.e., B. pendula Roth (silver birch) and tetraploid B. pubescens Ehrh. (downy birch), and two small shrub birch species, $B$. humilis Schrank (shrub birch of Central and Eastern Europe, Eurasia and Asia) and B. nana (dwarf arctic birch). Numerous other species present in Europe are con-

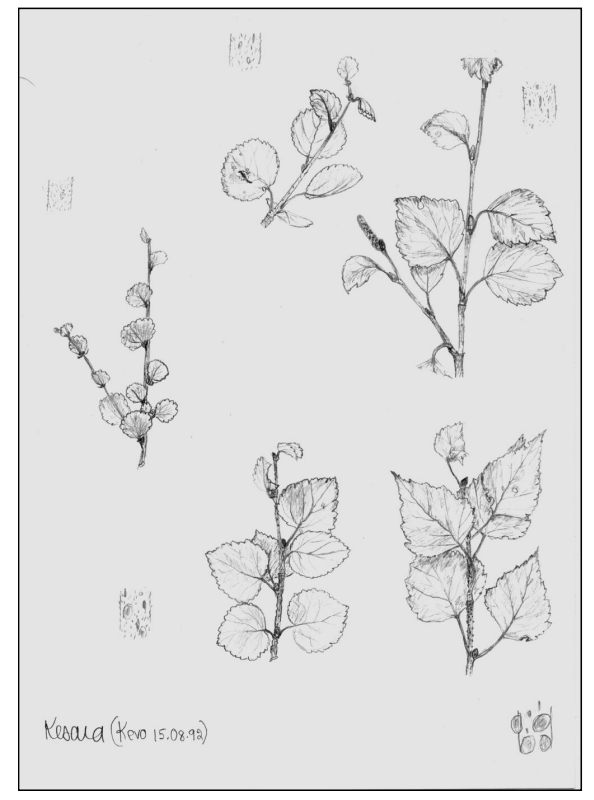

Fig. 1 Specimens of Betula species and putative hybrids collected from the forest in Evalo, Inari, northern Finland (drawing made by the author of this paper). Counter clockwise from bottom right: $B$. pendula, hybrid between $B$. pendula and $B$. nana, $B$. nana, hybrid between $B$. nana and $B$. pubescens, and B. pubescens.

sidered to be conspecific to the above-mentioned species or are treated as subspecies, geographical variants and hybrids. In northern Europe, all three birch species (B. humilis not counted) can be found together in the areas of overlapping distribution, i.e., from just below $70^{\circ} \mathrm{N}$ down to $55^{\circ} \mathrm{N}$, and in these areas, plants with intermediate morphology (putative hybrids) occur. During my visit to Evalo $\left(68^{\circ} 39^{\prime} \mathrm{N}\right)$, Finnish Lapland, on the way to Kevo Subarctic Research Institute in Utsjoki, I recorded specimens of all three birch species of northern Europe, i.e., B. pendula, B. pubescens and B. nana, as well as putative hybrids of $B$. nana either with $B$. pendula or with $B$. pubescens (Fig. 1). Birch with intermediate morphology is quite common throughout the distribution range of these species ${ }^{25-27}$.

Two species of Betula coexist in Iceland: the diploid $(2 \mathrm{n}=2 \mathrm{x}=28)$ dwarf birch (B. nana) and the tetraploid $(2 \mathrm{n}=4 \mathrm{x}=56)$ downy birch (B. pubescens), and they hybridize in their natural habitats ${ }^{27}$. Both species are found together in most areas, although downy birch occupies lower elevations and drier habitats compared with dwarf birch, which is more prevalent in the interior highlands and at colder sites. Betula nana, a circumpolar 


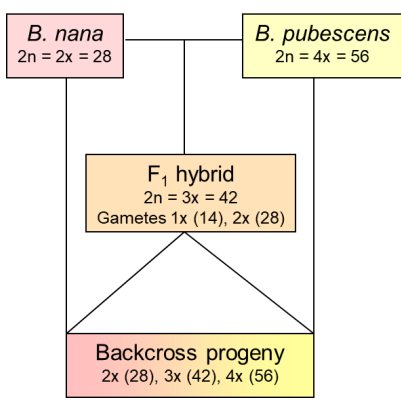

Fig. 2 Diagram showing the most probable process of introgressive hybridization in Betula as described in this paper.

species, is a prostrate shrub up to $1 \mathrm{~m}$ in height. Taxonomically, the species is represented by subspecies nana (Suk.) Hultén in Europe and Western Asia, and by subspecies exilis (Suk.) Hultén in North America and Central and Eastern Asia ${ }^{28}$. Only the subspecies nana is found in Iceland. On the other hand, B. pubescens is a European species ${ }^{22,28}$. It may grow up to $25 \mathrm{~m}$ tall, but in Iceland this birch is shrub-like. Natural woodlands, presently covering around $1.5 \%$ of the total land area ${ }^{29}$, are composed of $80 \%$ birch shrub less than $2 \mathrm{~m}$ in height ${ }^{30}$. Similar birch shrub, often referred to as mountain birch, is found in Fennoscandia, northern Russia, the Kola Peninsula and the European mountain regions ${ }^{31,32}$. The taxonomy of mountain birch has been problematic due to the very large morphological variation within downy birch species ${ }^{25}$. As a result, mountain birch has alternatively been given the status of species (e.g., B. tortuosa Ledeb.), subspecies (e.g., $B$. pubescens tortuosa (Ledeb.) Nyman) or variants (e.g., B. odorata var. tortuosa (Ledeb.) Rosenv.). In this paper and in all previous papers from my group, the name $B$. pubescens s.lat. is used to represent the one collective species, as proposed by Löve and Löve ${ }^{33}$.

Shrub-like B. pubescens was originally proposed to be the result of introgressive hybridization with B. nana, via their interspecific hybrids ${ }^{34}$, based on the morphology of downy birch in the north-western region of Iceland. This concept was further applied to explain the shrub-like morphology of mountain birch in Fennoscandia ${ }^{35}$. Some years later, crossing experiments with Icelandic birch showed that introgressive hybridization was the best possible explanation for the morphological variation among the progenies of backcrosses of triploid hybrids ${ }^{36}$. Prior to these crossing experiments, I succeeded in developing an effective method for birch chromosome preparation from root tips, and that was the beginning of my research on birch introgression ${ }^{37}$. Hybrids between species with different ploidy levels can be confirmed cytogenetically and such is the case with birch hybrids found in Iceland. Hybridization between diploid $B$. nana and tetraploid B. pubescens produces triploid $(2 \mathrm{n}=3 \mathrm{x}=42)$ hybrids. In these experiments ${ }^{36}$, triploid hybrids were made by pollinating female catkins of $B$. nana with pollen from $B$. pubescens, and the F1 hybrids were then backcrossed with pollen from either $B$. nana or B. pubescens producing F2 progenies belonging to three ploidy levels, diploid, triploid and tetraploid (Fig. 2). No aneuploid birch individuals were detected.

Many years later I developed a new protoplast dropping method for chromosome preparation from shoot tips or leaf buds collected in the field ${ }^{38}$ and this has made it possible for cytogenetic investigation of birches at a population level. Using this method, chromosome numbers were then obtained from birch plants growing in woodlands all around Iceland ${ }^{39-41}$. Of the 461 plants examined, 176 plants (38.2\%) are diploid, 241 plants (52.3\%) are tetraploid and 44 plants (9.5\%) are triploid hybrids ${ }^{41}$. Natural triploids presumably comprise mixed generation hybrids. The three ploidy groups were confirmed by genome size analysis on a subset of samples based on flow cytometry and DNA densitometry ${ }^{42}$. Again, no aneuploid was found. Aneuploids have never been found among birch plants in nature, or from crosses.

I therefore hypothesized that viable gametes produced by the triploid plants, although in extremely low frequencies, must have been euploid gametes with $n=14$ (B. nana type) or 28 (B. pubescens type) (Fig. 2), most probably derived via a meiotic non-disjunction. My recent study of male meiosis of triploid birch ${ }^{43}$ indicated two sizes of pollen. The morphometric measurement of pollen from numerous triploid plants ${ }^{44}$ shows that, based on the pattern of pollen size distribution within plants, triploid hybrids produce two sizes of triporate (normal) pollen grains. Thus pre-zygotic selection against aneuploid gametes must have been very strong. Barriers to gene flow, pre- or postzygotic, are thought to serve as a means to maintain a stable birch hybrid zone where the two hybridizing Betula species are able to coexist, in the same way as with numerous cases of plant hybridization ${ }^{45-47}$. The existence of triploid birch hybrids must have therefore served primarily as a bridge to gene flow 


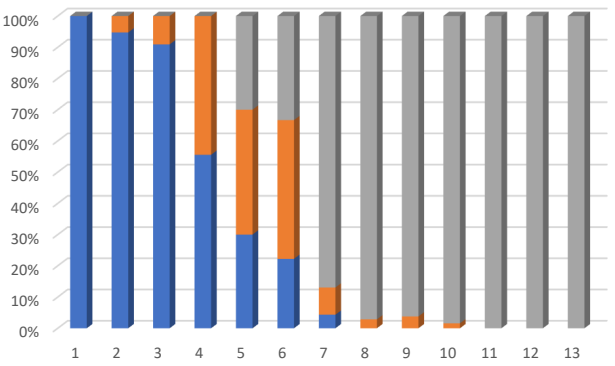

Fig. 3 Proportions of plants from different ploidy groups in each morphological class, from one (B. nana morphology) to thirteen (B. pubescens morphology): diploid (blue), triploid (orange) and tetraploid (grey). Introgression in Icelandic birch is evidently bi-directional.

between the two species via backcrossing, i.e., introgressive hybridization. By far the most positive outcome of hybridization is introgression that maintains the existing differentiation; however, with the potential for future adaptation or divergence when circumstances change ${ }^{14,17,48,49}$. Understanding the sterility of interspecific hybrids is also important, in the evolutionary context. While fertility facilitates gene flow between species, sterility itself functions as a reproductive barrier preventing native parental species from extinction.

\section{Hybrid introgression in birch - botanical and molecular investigations}

Based on floristic characters it should be possible to distinguish between dwarf birch Belula nana and downy birch B. pubescens ${ }^{22-24}$ (Fig. 1). Their hybrids presumably have intermediate morphology. However, in the field, there is a huge range of morphological variation, especially in B. pubescens, and due to the introgressive hybridization described above it is not possible to know, for example, if a plant is an interspecific hybrid or an introgressed birch. Hence in my research group, we first sorted the plants from all major woodlands in Iceland into the three ploidy groups, i.e., diploid $(2 \mathrm{n}=28)$, triploid $(2 n=42)$ and tetraploid $(2 n=56)$ groups, then scored individual plants in each ploidy group based on morphology ${ }^{39-41}$. The results are shown in Fig. 3.

The so-called morphology index, based on species-specific botanical characteristics ${ }^{34,50,51}$, was used to score individual ploidy-identified birch plants. Characters such as growth form and habit were assessed in the field. On the other hand, leaf characters were scored from 30 randomly collected leaves per plant, and one representative score for each character from each plant was obtained, as leaf shape characters turned out to be highly uniform within plants. The scores were assigned to place $B$. nana at the lowest ranks (from one up, as in Fig. 3) and B. pubescens at the highest (from 14 down, as in Fig. 3, but the Icelandic birch samples only reached 13 ). True $B$. nana would be a low shrub less than $1 \mathrm{~m}$ in height, with procumbent growth habit and sessile petioles, whereas its leaf is characterized by orbicular leaf shape, with rounded base and obtuse leaf tip, and leaf margin crenate with single teeth. According to floras, B. pubescens is a tree or a shrub higher than $1 \mathrm{~m}$, with erect growth habit. Its leaf has non-sessile petiole and is characterized by ovate shape, acute tip, cuneate base, and leaf margin dentate with multiple teeth. An intermediate leaf shape would be obovate, with subacute tip, cordate base and serrate leaf margin. For each plant, the scores of all characters are combined into a single value called a morphology index, and this was plotted against ploidy of the plants.

By scoring morphology indices, we were able to separate the diploid and the tetraploid groups most of the time (Fig. 3). The diploid group consisted mostly of dwarf birch B. nana (scores 1-3), but some diploid plants reached as high score as 7 , meaning that a diploid plant can look very much like a hybrid. About $23 \%$ of the diploid plants had the minimum score of one, which is taxonomically equivalent to being pure $B$. nana. This true type of $B$. nana is particularly common in the dwarf birch highland. The tetraploid group included B. pubescens-like plants (scores 8-13). Taxonomically, the maximum score for $B$. pubescens should be 14, but none of our tetraploid plants have this morphology. In other words, we have not found pure $B$. pubescens in natural birch woodlands in Iceland so far. Some tetraploid plants had scores all the way down to 5 , meaning that many of them are seen as hybrids. Thus the two ploidy groups showed an apparent overlapping region (scores 57). The triploid plants showed as wide range of scores as the other two groups, i.e., scores 210 , however, the majority of them fell within the 4-6 range. Practically, plants with intermediate morphology can be diploid, triploid, or tetraploid. Hence the introgression in Icelandic birch is clearly bi-directional, i.e., gene flow via triploid hybrids must have occurred in both directions, from diploid $B$. nana to tetraploid B. pubescens and in the opposite direction. However, gene flow from the diploid to 
the tetraploid level appears to be more prevalent in the case of woodland birch in Iceland (Fig. 3). A similar case of asymmetrical gene flow between B. nana and B. pubescens over a broad geographical range of northern Europe was detected in the molecular study of Eidesen et $\mathrm{al}^{52}$.

Quantitative evaluation of introgression was made on the same ploidy-identified plants as those in the qualitative analysis of morphology index described above ${ }^{41}$. The leaf morphology analysis program WinFolia (Regent Instruments, Canada) was used to generate numerical data about different leaf shape characters. The analysis was performed for nine variables, including leaf area, leaf width and length (including petiole), blade length and shape, lobe angle and petiole area. The multivariate ANOVA (MANOVA) was used to test the differentiation among ploidy groups and among sites within each group, whereas the linear discriminant analysis was conducted to evaluate how the variables can be used to classify the different individuals. The overall results strongly support the introgression study based on the morphology index. The linear discriminant analysis reveals significant separation among the three ploidy groups and the model assigned $96 \%$ and $97 \%$ of the B. nana and B. pubescens individuals correctly. The triploid hybrids are difficult to predict since only half of them could be assigned correctly.

Most interestingly, there is a clear indication of geographical structure among the woodlands investigated when the ploidy groups were analysed separately. High level of introgression in the leaf morphology was often found in the woodlands where summer is cold (often associated with glacial sites or the interior highlands), whereas the least introgression was detected among birch in the woodlands in lowland areas. Our molecular analysis of birch introgression based on chloroplast DNA haplotype variations ${ }^{53}$ supported the botanical study. All common haplotypes were shared between the triploid group and the parental species, indicating introgressive hybridization, and this was supported by the statistical analysis of introgression ratios (IG indices) and the variation components. This molecular study has also found a geographical structure of introgression, very much in the same way as that shown in the morphological study.

Shrub-like birch with intermediate or hybridlike morphology is also known to be common in regions characterized by cold climates, such as Fennoscandia, the highland areas of Scandinavia, other mountain regions of Europe, and southern Greenland ${ }^{54-57}$. In the northern part of the Urals and Western Siberia, in the region of forest tundrataiga, changes in leaf parameters in $B$. pubescens including shape and complexity were found to correlate with climatic conditions such as long-term average temperatures ${ }^{58}$; this may have physiological advantages, especially in photosynthesis. Such morphological differentiation is likely to be driven by the introgressive hybridization process, if the introgressant types are more adaptable (or more tolerant) to environmental pressure and habitats such as those found in Iceland and elsewhere in the subarctic regions. This introgressed downy birch can have certain advantages: for example the ability to spread vegetatively and form a large multicormic shrub could ensure survival of the plant in extreme environments. A molecular study on alpine sedge has shown that genotype integrity is maintained in optimal habitats, whereas introgressed individuals are favoured in marginal habitats ${ }^{59}$. Recent genomic and functional analyses by Suarez-Gonzalez et $\mathrm{al}^{16}$ revealed a case of adaptive introgression in aspen (Populus), whereby introgressed individuals harbouring alleles for an effective light response were prevalent in the northern, colder and drier regions, but those without the introgressed region were common in warmer and wetter area in the coastal and southern regions. Furthermore, the adaptive introgression in this aspen inferred plant disease resistance as well ${ }^{60}$. In conclusion, the introgressive hybridization in birch revealed here is likely to be of adaptive significance in a fluctuating environment, for the segregating hybrids as well as for the two species, via backcrossing.

\section{Birch hybridization and climate warming}

The botanical and molecular results described above indicate a rare occurrence of birch plants that have all of the species-specific morphological characters (i.e., pure species). Although some $20 \%$ of the diploid plants were scored as being morphologically pure $B$. nana, especially those in the interior highland too high altitudes for downy birch, no pure B. pubescens was found in natural woodlands in Iceland. This can only indicate that the backcrossing of the hybrids (i.e., introgressive hybridization) has been happening for a long time, especially in the direction from the diploid to the tetraploid level. We therefore began our palynological study in 2007, with the aim of constructing the history of birch introgression in Iceland since the early Holocene by using morphometric characters specific to pollen of triploid plants. The studies of pollen deposits and palaeoclimatic records in Iceland ${ }^{61}$ indicate a 


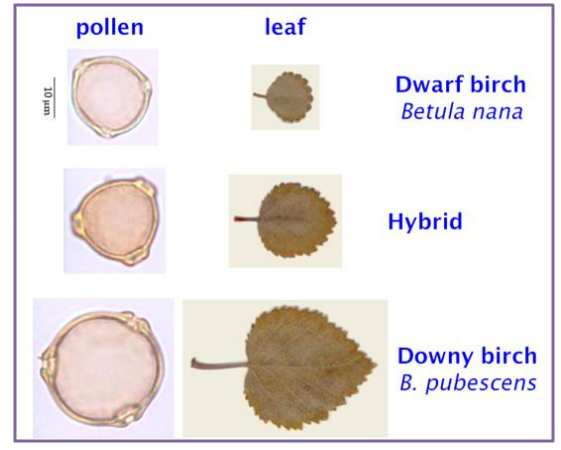

Fig. 4 Typical pollen and leaf of diploid B. nana, triploid hybrid and tetraploid B. pubescens. Normal (presumably viable) Betula pollen is triporate, having three pores. Pollen micrographs were taken by Lilja Karlsdóttir. Ægir Thór Thórsson karyotyped most plants and provided the leaf samples.

phase when there could be considerable hybridization between the well-established $B$. nana and the incoming form of tree birch $B$. pubescens, apparently by postglacial migration from north-western regions of Europe ${ }^{53}$. Similar palynological and macrofossil analysis provides evidence for the occurrence of birch hybrids in the phases of subarctic conditions during the Late Glacial Period in large parts of north-west Europe ${ }^{62}$. Recent study by Wang et al ${ }^{63}$ detected a molecular footprint of the Holocene retreat of dwarf birch in Britain, presumably due to hybridization and introgressive replacement by treebirch species.

First we constructed standards of pollen measurements using samples obtained from the ploidyidentified, present-day birch plants from natural woodlands: from diploid B. nana and tetraploid B. pubescens ${ }^{64}$ and from triploid hybrids ${ }^{44}$. Pollen from 22 triploid trees/shrubs from ten woodlands in Iceland was examined and its size and shape compared with pollen from the parental species. Triploid birch plants can produce normal and viable pollen, however with very low frequencies ${ }^{43}$. When comparing normal (presumably viable), triporate pollen (pollen grain with three pores), pollen grains from the triploid hybrids are on average as small as $B$. nana pollen, which is statistically smaller than $B$. pubescens pollen, but the size of the vestibulum (the pore) is similar to that of $B$. pubescens, which is bigger and thicker than that of $B$. nana (Fig. 4). Several anomalies in pollen morphology were found to be common among pollen grains from the triploid hybrids: four or more pores were the most frequent type of abnormality. Characteristics of the pollen of triploid Betula hybrids, especially structural anomalies, have provided us with a means to reveal periods of interspecific hybridization in the analysis of subfossil pollen.

Present-day birch in Iceland is most probably postglacial in origin, i.e., having colonized Iceland in the early Holocene. The first colonization of Holocene birch is believed to have occurred in the north and north-eastern valleys and this is thought to be the result of different deglaciation patterns in that area, together with early-Holocene warming in northern Iceland. The Holocene vegetation history constructed from pollen records from lake sediments and macroscopic remains in peat ${ }^{65,66}$ supports the hypothesis that birch woodland (dominated by the tree-birch species $B$. pubescens) started to form in the north-eastern valleys of Skagafjördur and Eyjafjördur in the Late Boreal and progressed into the western fjords and southern Iceland towards the end of the Atlantic period. We therefore started our palynological investigations in the north, at Hella in Eyjafjördur ${ }^{67}$, where the vegetation history is well-documented. We then examined birch pollen from the peat monolith covering the first three thousand years of the Holocene, from the location Eyvík, in the south-western region where the vegetation history began quite late ${ }^{68}$. Lastly, we constructed a full pollen profile from the peat monolith covering the last ten thousand years of the Holocene, from the farm Ytra-Áland in Thistilfjördur, North-east Iceland ${ }^{69}$, the region we know very little about its vegetation history. Our molecular study, based on DNA haplotype variation ${ }^{53}$, revealed that birch in north-eastern regions has different origin from birch in south-western regions. The palynological results from all three diverse sites were compiled and analysed together in Karlsdót$\operatorname{tir}^{70}$.

The combined results from all three locations, i.e., Hella, Eyvík and Ytri-Áland, show two periods of elevated proportions of abnormal Betula pollen (the strongest evidence of hybridization): the earlier period from approximately 9.3 to $7.3 \mathrm{cal}$ ka BP (calibrated time before present) and the later from approximately 5.0 to 3.5 cal ka BP. By comparison to climate data from the Greenland Ice Core Project $^{71}$, the effect of climate on birch woodlands could be seen. The hybridization periods were found to be connected to the advance of woodland forming downy birch over dwarf birch habitat under warming climate. The early period fell within the Holocene Thermal Maximum (HTM) in terrestrial 
Iceland, which has been estimated between 10.3 and $5.6 \mathrm{cal} \mathrm{ka} \mathrm{BP72}$, and the peak may have been about $7.1 \mathrm{cal} \mathrm{ka} \mathrm{BP}$, with the summer temperatures almost $1.5^{\circ} \mathrm{C}$ above the averages of the 20 th century ${ }^{73}$. The frequencies of non-triporate pollen (i.e., hybridization) during the first birch woodland establishment in Iceland far exceeded the average level produced by the present-day triploid hybrids. The later period probably fell within the delayed HTM in North-eastern Iceland, coinciding with warming periods of the boreal based on the Greenland Ice Core Project ${ }^{71}$. Climatic and ecological conditions may have favoured hybridization of birch species during the expansion of birch woodlands in warm periods. Based on the molecular study of Eidesen et $\mathrm{al}^{52}$, the gene flow between B. nana and B. pubescens over a broad geographical range also appears to be frequent during the postglacial expansion front of $B$. pubescens. In conclusion, a warmer climate has been shown to promote birch hybridization, and with the warming of climate in the last few decades a new wave of birch hybridization has started in Iceland.

\section{Ongoing research and future prospects}

Our current and ongoing work uses bi-parentally inherited nuclear DNA markers to further resolve the phylogeographical pattern of birch in Iceland and to trace the probable postglacial migration of the woodland downy birch westwards from Europe. Genome-wide nuclear markers offer excellent within-species resolution, and are hence useful for dissecting genetic variation due to founder effects, genetic drift, bottleneck effects, gene flow and other evolutionary forces. Preliminary results show that regardless of extensive gene flow, the two Betula species are genomically stable.

The unique feature of our Betula research is that we have karyotyped plants in natural woodlands, meaning that our continuing molecular studies can answer specific questions about hybridization and introgression. Once correlated to present-day and past biogeography, it will be possible to predict future changes due to human influences and global warming. We have already found evidence of frequent hybridization coinciding with warming periods during the Holocene, and therefore the next immediate step is to focus on the anthropogenic hybridization, whereby human activity has been the dominant influence on climate and the environment. The karyotyped plants in woodlands, with their individual-based introgression indices, can be an important resource for the functional genomic studies that allow identification of adaptive genes for Betula in the arctic environment.

Acknowledgements: I would like to thank all my research students for their expertise and dedication to our research on birch introgression, in particular Ægir Thór Thórsson and Lilja Karlsdóttir. I thank the following persons who have contributed to a better understanding of Icelandic birch over the years: Thorsteinn Tómasson, Peter Tigerstedt, Áskell Löve, Pat Heslop-Harrison, Mark Atkinson, Matti Sulkinoja, Adalsteinn Sigurgeirsson, Elina Salmila, Irma Saloniemi, Vignir Sigurdsson, Thröstur Eysteinsson, Martin Lascoux, Snæbjörn Pálsson, Margrét Hallsdóttir, Magnús Jóhannsson, Anna Palmé, Kenneth Hoegh, Ólafur Eggertsson, Johann Greilhuber, Eva Temsch and G. Benjamin Leduc. This birch research has been funded by the Icelandic Research Centre (Rannís) and the Research Fund of the University of Iceland.

\section{REFERENCES}

1. Anderson E (1953) Introgressive hybridization. Biol Rev 28, 280-307.

2. Heiser CB Jr (1973) Introgression re-examined. Bot Rev 39, 347-366.

3. Rieseberg LH (1997) Hybrid origins of plant species. Annu Rev Ecol Syst 28, 359-389.

4. Mallet J (2007) Hybrid speciation. Nature 446, 279-283.

5. Ellstrand NC, Whitkus RW, Rieseberg LH (1996). Distribution of spontaneous plant hybrids. Proc Natl Acad Sci USA 93, 5090-5093.

6. Gross BL, Rieseberg LH (2005) The ecological genetics of homoploid hybrid speciation. $J$ Hered 96 , 241-252.

7. Rieseberg LH, Willis JH (2007) Plant speciation. Science 317, 910-914.

8. Rice A, Smarda P, Novosolov M, Drori M, Glick L, Sabath N, et al (2019) The global biogeography of polyploid plants. Nature Ecol Evol 3, 265-273.

9. Puangpairote T, Maknoi C, Jenjittikul T, Anamthawat-Jónsson K, Soontornchainaksaeng $P$ (2016) Natural triploidy in phyto-oestrogen producing Curcuma species and cultivars from Thailand. Euphytica 208, 47-61.

10. Rhymer JM, Simberloff D (1996) Extinction by hybridization and introgression. Annu Rev Ecol Syst 27, 83-109.

11. Ellstrand NC, Prentice HC, Hancock JF (1999) Gene flow and introgression from domestic plants into their wild species. Annu Rev Ecol Syst 30, 539-563.

12. Jarvis DI, Hodgkin T (1999) Wild relatives and crop cultivars: detecting natural introgression and farmer selection of new genetic combinations in agroecosystems. Mol Ecol 8, S159-S173.

13. Minder AM, Widmer A (2008) A population genomic analysis of species boundaries: neutral processes, 
adaptive divergence and introgression between two hybridizing plant species. Mol Ecol 17, 1552-1563.

14. Burgarella C, Barnaud A, Kane NA, Jankowski F, Scarcelli N, Billot C, et al (2019) Adaptive introgression: An untapped evolutionary mechanism for crop adaptation. Front Plant Sci 10, 4.

15. Anamthawat-Jónsson K (2001) Molecular cytogenetics of introgressive hybridization in plants. Meth Cell Sci 23, 141-150.

16. Suarez-Gonzalez A, Hefer CA, Christe C, Corea O, Lexer C, Cronk QCB, et al (2016) Genomic and functional approaches reveal a case of adaptive introgression from Populus balsamifera (balsam poplar) in P. trichocarpa (black cottonwood). Mol Ecol 25, 2427-2442.

17. Abbott R, Albach D, Ansell S, Arntzen JW, Baird SJE, Bierne N, et al (2013) Hybridization and speciation. $J$ Evol Biol 26, 229-246.

18. Ellstrand NC (2014) Is gene flow the most important evolutionary force in plants? Amer $J$ Bot 101, 737-753.

19. Allendorf FW, Leary RF, Spruell P, Wenburg JK (2001) The problems with hybrids: setting conservation guidelines. Trends Ecol Evol 16, 613-622.

20. Woodworth RH (1929) Cytological studies in the Betulaceae. I. Betula. Bot Gazette 87, 331-363.

21. Johnsson $H$ (1945) Interspecific hybridisation within the genus Betula. Hereditas 31, 163-176.

22. Walters SM (1964) Betulaceae. In: Tutin TG, Heywood VH, Burges NA, Valentine DH, Walters SM, Webb DA (eds) Flora Europaea 1, Cambridge University Press, Cambridge, pp 57-59.

23. Furlow JJ (1997) Betulaceae Gray. Birch family. In: Flora of North America Committee (ed) Flora of North America, north of Mexico 3, Oxford University Press, New York, pp 507-538.

24. Ashburner K, McAllister HA (2013) The Genus Betula: A Taxonomic Revision of Birches, Royal Botanic Garden Kew Publishing, London.

25. Atkinson MD (1992) Biological flora of the British Isles, No. 175: Betula pendula Roth. (B. verrucosa Ehrh.) and B. pubescens Ehrh. $J$ Ecol 80, 837-870.

26. De Groot WJ, Thomas PA, Wein RW (1997) Betula nana L. and Betula glandulosa Michx. J Ecol 85, 241-264.

27. Anamthawat-Jónsson K (2012) Hybridisation, introgression and phylogeography of Icelandic birch. In: Anamthawat-Jónsson K (ed) Current Topics in Phylogenetics and Phylogeography of Terrestrial and Aquatic Systems, InTech, Croatia, pp 117-144.

28. Hultén E, Fries M (1986) Atlas of North European Vascular Plants, Koeltz Scientific Books, Köningstein.

29. Snorrason A, Traustason B, Kjartansson BT, Heidarsson L, ísleifsson R, Eggertsson Ó (2016) The natural birch woodland in Iceland - a new assessment on distribution and state. Natturufraedingurinn 86, 87-111. [In Icelandic]
30. Traustason B, Snorrason A (2008) Spatial distribution of forests and woodlands in Iceland in accordance with the CORINE land cover classification. Icel Agr Sci 21, 39-47.

31. Wielgolaski FE (2001) Vegetation sections in northern Fennoscandian mountain birch forests. In: Wielgolaski FE (ed) Nordic Mountain Birch Ecosystems, The Parthenon Publishing Group, NY, pp 23-34.

32. Tsuda Y, Semerikov V, Sebastiani F, Vendramin GG, Lascoux M (2017) Multispecies genetic structure and hybridization in the Betula genus across Eurasia. Mol Ecol 26, 589-605.

33. Löve Á, Löve D (1956) A cytotaxonomical conspectus of the Icelandic flora. Acta Horti Gothobergensis 20, 65-290.

34. Elkington TT (1968) Introgressive hybridization between Betula nana L. and B. pubescens Ehrh. in NorthWest Iceland. New Phytol 67, 109-118.

35. Vaarama A, Valanne T (1973) On the taxonomy, biology and origin of Betula tortuosa Ledeb. Rep Kevo Subarc Res Stat 10, 70-84.

36. Anamthawat-Jónsson K, Tómasson Th (1990) Cytogenetics of hybrid introgression in Icelandic birch. Hereditas 112, 65-70.

37. Anamthawat-Jónsson K, Atipanumpai L, Tigerstedt PMA, Tómasson Th (1986) The Feulgen-Giemsa method for chromosomes of Betula species. Hereditas 104, 321-322.

38. Anamthawat-Jónsson K (2004) Preparation of chromosomes from plant leaf meristems for karyotype analysis and in situ hybridisation. Meth Cell Sci 25, 91-95.

39. Anamthawat-Jónsson K, Thórsson ÆTh (2003) Natural hybridisation in birch: triploid hybrids between Betula nana and B. pubescens. Plant Cell Tiss Organ Cult 75, 99-107.

40. Thórsson ÆTh, Salmela E, Anamthawat-Jónsson K (2001) Morphological, cytogenetic, and molecular evidence for introgressive hybridization in birch. $J$ Hered 92, 404-408.

41. Thórsson ÆTh, Pálsson S, Sigurgeirsson A, Anamthawat-Jónsson K (2007) Morphological variation among Betula nana (diploid), B. pubescens (tetraploid) and their triploid hybrids in Iceland. Ann Bot-London 99, 1183-1193.

42. Anamthawat-Jónsson K, Thórsson ÆTh, Temsch EM, Greilhuber J (2010) Icelandic birch polyploids - the case of perfect fit in genome size. $J$ Bot, ID 347254.

43. Anamthawat-Jónsson K (2018) Triploid birch hybrids. Fluorescence imaging of birch mitosis and meiosis. Imaging \& Microscopy 20, 18-21.

44. Karlsdóttir L, Hallsdóttir M, Thórsson ÆTh, Anamthawat-Jónsson K (2008) Characteristics of pollen from natural triploid Betula hybrids. Grana 47, 52-59.

45. Wolf DE, Takebayashi N, Rieseberg LH (2001) Predicting the risk of extinction through hybridization. 
Conserv Biol 15, 1039-1053.

46. Ramsey J, Schemske DW (2002) Neopolyploidy in flowering plants. Annu Rev Ecol Syst 33, 589-639.

47. Todesco M, Pascual MA, Owens GL, Ostevik KL, Moyers BT, Hubner S, et al (2016) Hybridization and extinction. Evol Appl 9, 892-908.

48. Barton NH (2001) The role of hybridization in evolution. Mol Ecol 10, 551-568.

49. Ellstrand NC, Rieseberg LH (2016) When gene flow really matters: gene flow in applied evolutionary biology. Evol Appl 9, 833-836.

50. Clapham AR, Tutin TG, Warburg EF (1962) Flora of the British Isles, 2nd edn, Cambridge University Press, Cambridge.

51. Kenworthy JB, Aston D, Bucknall SA (1972) A study of hybrids between Betula pubescens Ehrh. and Betula nana L. from Sutherland - an integrated approach. Trans Bot Soc Edinb 41, 517-539.

52. Eidesen PB, Alsos IG, Brochmann C (2015) Comparative analyses of plastid and AFLP data suggest different colonization history and asymmetric hybridization between Betula pubescens and B. nana. Mol Ecol 24, 3993-4009.

53. Thórsson ÆTh, Pálsson S, Lascoux M, AnamthawatJónsson K (2010) Introgression and phylogeography of Betula nana (diploid), B. pubescens (tetraploid) and their triploid hybrids in Iceland inferred from cpDNA haplotype variation. J Biogeogr 37, 2098-2110.

54. Kallio P, Niemi S, Sulkinoja M (1983) The Fennoscandian birch and its evolution in the marginal forest zone. Nordicana 47, 101-110.

55. Gardiner AS (1984) Taxonomy of infraspecific variation in Betula pubescens Ehrh., with particular reference to the Scottish Highlands. Proc Royal Soc Edinb 85, 13-26.

56. Sulkinoja M (1990) Hybridization, introgression and taxonomy of the mountain birch in SW Greenland compared with related results from Iceland and Finnish Lapland. Meddelelser Grönland Biosci 33, 21-29.

57. Jetlund S (1994) Introgressive hybridisation between the birch species (Betula pubescens ssp. tortuosa) and Betula nana in the mountains in Gudbrandsdalen, Norway. Norw J Agr Sci 18, 15-18.

58. Migalina S, Ivanova LA, Makhanev AK (2010) Changes of leaf morphology in Betula pendula Roth and B. pubescens Ehrh. along a zonal-climatic transect in the Urals and Western Siberia. Russ J Ecol 41, 293-301.

59. Choler P, Erschbamer B, Tribsch A, Gielly L, Taberlet P (2004) Genetic introgression as a potential to widen a species' niche: Insights from alpine Carex curvula. Proc Natl Acad Sci USA 101, 171-176.

60. Suarez-Gonzalez A, Hefer CA, Lexer C, Cronk QC, Douglas CJ (2018) Scale and direction of adaptive introgression between black cottonwood (Populus trichocarpa) and balsam poplar (P. balsamifera). Mol
Ecol 27, 1667-1680.

61. Caseldine, C (2001) Changes in Betula in the Holocene record from Iceland - a palaeoclimatic record or evidence for early Holocene hybridisation? Rev Palaeobot Palyn 117, 139-152.

62. Wagner F, Neuvonen S, Kurschner WM, Visseher H (2000) The influence of hybridisation on epidermal properties of birch species and the consequences for palaeoclimatic interpretations. Plant Ecol 148, 61-69.

63. Wang N, Borrell JS, Bodles WJ, Kuttapitiya A, Nichols RA, Buggs RJ (2014) Molecular footprints of the Holocene retreat of dwarf birch in Britain. Mol Ecol 23, 2771-2782.

64. Karlsdóttir L, Thórsson ÆTh, Hallsdóttir M, Sigurgeirsson A, Eysteinsson T, Anamthawat-Jónsson K (2007) Differentiating pollen of Betula species from Iceland. Grana 46, 78-84.

65. Hallsdóttir M (1995) On the pre-settlement history of Icelandic vegetation. Icel Agr Sci 9, 17-29.

66. Hallsdóttir M, Caseldine CJ (2005) The Holocene vegetation history of Iceland, state-of-theart and future research. In: Caseldine C, Russell A, Hardardóttir J, Knudsen Ó (eds) Iceland - Modern Processes and Past Environments, Elsevier, Amsterdam, pp 319-334.

67. Karlsdóttir L, Hallsdóttir M, Thórsson ÆTh, Anamthawat-Jónsson K (2009) Evidence of hybridisation between Betula pubescens and B. nana in Iceland during the early Holocene. Rev Palaeobot Palyn 156, 350-357.

68. Karlsdóttir L, Hallsdóttir M, Thórsson ÆTh, Anamthawat-Jónsson K (2012) Early Holocene hybridisation between Betula pubescens and B. nana in relation to birch vegetation in Southwest Iceland. Rev Palaeobot Palyn 181, 1-10.

69. Karlsdóttir L, Hallsdóttir M, Eggertsson Ó, Thórsson ÆTh, Anamthawat-Jónsson K (2014) Birch hybridization in Thistilfjördur, Northeast Iceland during the Holocene. Icel Agr Sci 27, 95-109.

70. Karlsdóttir L, Hallsdóttir M, Thórsson ÆTh, Anamthawat-Jónsson K (2016) Hybridisation of downy birch and dwarf birch in the Holocene). Natturufraedingurinn 86, 19-27. [In Icelandic]

71. Bond G, Showers W, Cheseby M, Lotti R, Almasi P, Demenocal P, et al (1997) A pervasive millennialscale cycle in North Atlantic Holocene and glacial climates. Science 278, 1257-1266.

72. Kaufman DS, Ager TA, Anderson NJ, Anderson PM, Andrews JT, Bartlein PJ, et al (2004) Holocene thermal maximum in the western Arctic $\left(0-180^{\circ} \mathrm{W}\right)$. Quatern Sci Rev 23, 2059-2060.

73. Wastl M, Stötter J, Caseldine C (2001) Reconstruction of Holocene variations of the upper limit of tree or shrub birch growth in northern Iceland based on evidence from Vesturárdalur-Skídadalur, Tröllaskagi. Arctic Antarctic Alpine Res 33, 191-203. 